\title{
Age-dependent Expression of the Erythropoietin Gene in Rat Liver and Kidneys
}

Kai-Uwe Eckardt, ${ }^{\star}$ Peter J. Ratcliffe, ${ }^{\star}$ Chorh C. Tan, ${ }^{\star}$ Christian Bauer, and Armin Kurtz

Physiologisches Institut der Universität Zürich, CH 8057 Zürich, Switzerland; and *Institute of Molecular Medicine, John Radcliffe Hospital, OX3 9DU Oxford, United Kingdom

\begin{abstract}
Using RNAse protection, we have made quantitative measurements of erythropoietin (EPO) mRNA in liver and kidneys of developing rats (days 1-54), to determine the relative contribution of both organs to the total EPO mRNA, to monitor changes which occur with development, and to compare the hypoxia-induced accumulation of EPO mRNA with the changes in serum EPO concentrations. To determine whether developmental and organ-specific responsiveness is related to the type of hypoxic stimulus, normobaric hypoxia was compared with exposure to carbon monoxide (functional anemia).

Under both stimuli EPO mRNA concentration in liver was maximal on day 7 and declined during development. In contrast, EPO mRNA concentration in kidney increased during development from day 1 when it was 30-65\% the hepatic concentration to day 54 when it was 12-fold higher than in liver. When organ weight was considered the liver was found to contain the majority of EPO mRNA in the first three to four weeks of life, and although, in stimulated animals, the hepatic proportion declined from $85-91 \%$ on day 1 , it remained $\sim 33 \%$ at day 54 and was similar for the two types of stimuli. When normalized for body weight the sum of renal and hepatic EPO mRNA in animals of a particular age was related linearly to serum hormone concentrations. However, the slope of this regression increased progressively with development, suggesting age-dependent alterations in translational efficiency or EPO metabolism. (J. Clin. Invest. 1992. 89:753-760.) Key words: RNase protection • radioimmunoassay $\bullet$ normobaric hypoxia $\bullet$ carbon monoxide $\bullet$ bilateral nephrectomy
\end{abstract}

\section{Introduction}

Erythropoietin (EPO) ${ }^{1}$ is a glycoprotein hormone that is produced in inverse relationship to blood oxygen content and determines the rate of red cell formation. The sites of EPO production were originally deduced from the results of organ ablation studies and more recently from the distribution of EPO mRNA. Although these studies have firmly established the liver and the kidneys as production sites for EPO, discrepancies

Address correspondence to K.-U. Eckardt, M.D., Physiologisches Institut der Universität Regensburg, Universitätsstrasse 31, DW 8400 Regensburg, Federal Republic of Germany, which is his present address. 1991 .

Received for publication 3 April 1991 and in revised form 3 October

1. Abbreviation used in this paper: EPO, erythropoietin.

J. Clin. Invest.

(C) The American Society for Clinical Investigation, Inc.

0021-9738/92/03/0753/08 \$2.00

Volume 89, March 1992, 753-760 exist and the relative importance of each organ has not been determined unequivocally.

Organ ablation studies have revealed that in adult animals the increase in serum EPO levels in response to hypobaric hypoxia is reduced by $\sim 80-90 \%$ after bilateral nephrectomy (1$3)$, the remaining EPO formation being abolished when nephrectomy is combined with subtotal hepatectomy (4). In fetal and neonatal animals, however, bilateral nephrectomy was found to have little or no effect on EPO formation, whereas hepatectomy almost completely prevented an increase in serum EPO concentrations under hypoxia (5-8). From a gradual change in the effect of nephrectomy and/or hepatectomy on EPO formation during development it was inferred that in sheep a shift of EPO production from liver to kidney is initiated during late gestation, with a hepatic contribution to EPO production of $\sim 70 \%$ around birth (9). In rats, moreover, the kidneys appeared to play no or little role in EPO formation for up to two weeks after birth, thereafter gradually gaining increasing importance $(2,3,10)$.

Detection of EPO mRNA by Northern blotting of extracts from different organs confirmed liver and kidney as the sites of EPO gene expression $(11,12)$. In adult animals the abundance of EPO mRNA in kidneys was much higher than that in liver $(11,12)$. Furthermore, in a recent study Koury et al. measured EPO mRNA levels in pooled extracts of kidneys and livers from developing normal and anemic mice using both Northern blotting and RNAse protection assay (13). They found the proportion of EPO mRNA in the liver decreasing with age, but, in contrast to what may be anticipated from the organ ablation studies, they observed that the kidneys contain most EPO mRNA soon after they become macroscopically identifiable, i.e., during late gestation and all stages of postnatal development.

Several possibilities could explain this apparent discrepancy between the ablation studies and the quantitative analysis of EPO mRNA with regard to the role of the liver in EPO formation. Thus it is possible that EPO formation after nephrectomy and/or hepatectomy may not accurately reflect the situation in intact animals. Furthermore, the role of the liver for EPO formation may be species specific and be of less importance in mice than in rats, goats, or sheep, or may depend on the kind of stimulus used and be less significant in anemia than in hypoxic hypoxia. Alternatively, the findings may indicate that the relationship between EPO production rates and EPO mRNA content varies between liver and kidney, i.e., that hepatic EPO mRNA is more efficiently translated than renal EPO mRNA.

The respective ability of liver and kidneys to produce EPO and the responsiveness of both organs to different stimuli appears of major importance not only for the regulation of erythropoiesis around birth, but may also have implications for EPO formation under conditions of compromised kidney function as in chronic renal disease. We have therefore addressed the 
above possibilities by studying the age dependence of EPO gene expression in rat kidneys and liver under basal conditions and following the exposure to normobaric (hypoxic) hypoxia and carbon monoxide (functional anemia). Both stimuli were applied for a short period of four hours to allow measurements at precisely timed and closely spaced points during the early postnatal phase and to avoid possible confounding effects from adaptive processes which have been observed with more prolonged exposure to hypoxic hypoxia $(14,15)$. To investigate if the duration of stimulation is of central importance in determining organ-specific responsiveness, additional experiments were performed on adult animals studied after three days of repetitive bleeding. The rat was chosen as experimental animal to enable a direct comparison with the evidence available from organ ablation studies. To further judge the significance of these organ ablation studies for EPO formation in the intact organism, we have also investigated the effect of nephrectomy on hepatic EPO gene expression. To allow a direct comparison between circulating EPO levels and EPO mRNA, serum EPO levels were determined by radioimmunoassay and EPO mRNA concentration was measured in kidneys and liver from individual animals using a quantitative RNAse protection assay.

\section{Methods}

Animals. ZUR: SIV strain rats of different ages were bred in the local animal house. Experiments were performed at ages $1 \mathrm{~d}, 7 \mathrm{~d}, 14 \mathrm{~d}, 28 \mathrm{~d}$, and $54 \mathrm{~d}$ postnatally. At ages 1,7 , and $14 \mathrm{~d}$ rats were kept together with their mother until immediately before the experiment. After the sex of the animals became identifiable, i.e., after $14 \mathrm{~d}$, male animals were used only.

Stimulation of EPO production. For study of the age-dependent changes of EPO gene expression normobaric hypoxic hypoxia or functional anemia caused by carbon monoxide inhalation were used to stimulate EPO formation. Animals were exposed to these stimuli for 4 $h$ in chambers that were gassed with a mixture of normal air and nitrogen or normal air with added carbon monoxide $(0.1 \%)$. During hypoxic hypoxia oxygen was gradually washed out of the chambers, reproducibly reaching a concentration of $11 \%$ after $1 \mathrm{~h}$ and a concentration of $8.5 \%$ after $4 \mathrm{~h}$, as determined by means of a fyrite oxygen indicator (Bacharach Inc., Pittsburgh, PA). Litter mates of the animals exposed to hypoxia were kept at normoxia and used for study of EPO formation under basal conditions.

Experiments with anemic animals. For study of the effect of more prolonged stimulation on EPO gene expression adult rats (6-7 wk old) were phlebotomized on three consecutive days. Under brief anesthesia with fenatyl citrate and fluanisone animals were bled $\sim 6.5,5.5$, and 5 $\mathrm{ml}$ from femoral veins on days $1-3$, respectively, using saline for volume replacement.

Experiments with nephrectomized animals. Bilateral nephrectomies were carried out in adult rats (6-7 wk old) under light methofane anesthesia through bilateral flank incisions. $7 \mathrm{~h}$ after the operation nephrectomized rats were exposed for $4 \mathrm{~h}$ to $0.1 \%$ carbon monoxide together with sham-operated control animals.

$24 \mathrm{~h}$ after the last phlebotomy (anemic animals), within $15 \mathrm{~min}$ after the end of carbon monoxide exposure, and within $30 \mathrm{~min}$ after the end of hypoxic hypoxia, animals were killed by decapitation (age 1-14 d) followed by direct collection of blood or by cervical dislocation (age 28-54 d), after which blood was collected from the abdominal aorta. Kidneys and livers were removed and after determination of wet weight kidneys were completely and livers were in part or completely homogenized in guanidine thiocyanate $(4 \mathrm{M})$ containing sarcosyl (0.5\%), EDTA (10 mM), sodium citrate $(25 \mathrm{mM})$, and mercaptoethanol $(700 \mathrm{mM})$. Different amounts of guanidine thiocyanate were used to maintain a constant concentration of $\sim 0.04 \mathrm{~g}$ tissue per $\mathrm{ml}$; except for the kidneys of $1-\mathrm{d}$ old animals, when the concentration was $0.02 \mathrm{~g}$ tissue per $\mathrm{ml}$. After several determinations in earlier experiments demonstrated that the concentration of EPO mRNA is the same in all lobes of the liver (16), weighed portions of the right lateral lobe were used in those experiments where only a portion of the liver was homogenized. Tissue homogenates were frozen at $-80^{\circ} \mathrm{C}$ until preparation of RNA.

$R N A s e$ protection assay. RNAse protection assay was performed as described (17). RNA was purified by centrifugation for $20 \mathrm{~h}$ at 33,000 rpm on a cesium chloride gradient (5.7 M CsCl and $100 \mathrm{mM}$ EDTA). After centrifugation RNA pellets were resuspended in $300 \mu \mathrm{l}$ TE (10 $\mathrm{mM}$ Tris, $1 \mathrm{mM}$ EDTA) containing $0.1 \%$ SDS, precipitated with $3 \mathrm{M}$ sodium acetate $(0.1 \mathrm{vol})$ and ethanol $(3 \mathrm{vol})$, and stored at $-80^{\circ} \mathrm{C}$ before analysis.

The rat EPO probe was a PstI/SacI fragment containing $132 \mathrm{bp}$ of exon $\mathrm{V}$ and $\sim 300$ bp of the adjoining intron, inserted into pSP 64 for generation of RNA transcripts. Transcripts were continuously labelled with alpha ${ }^{32} \mathrm{P}-\mathrm{GTP}(410 \mathrm{Ci} / \mathrm{mmol}$; Amersham International, Amersham, Bucks., UK). For hybridization aliquots of total RNA were dissolved in buffer ( $80 \%$ formamide, $40 \mathrm{mM}$ piperazine- $N, N$-bis(2-ethane sulfonic acid), $400 \mathrm{mM}$ sodium chloride, $1 \mathrm{mM}$ EDTA pH 8 ) and the RNA concentrations determined by measurement of optical density at $260 \mathrm{~nm}$. The concentration was adjusted to yield 50- $\mu$ l samples containing $100-150 \mu \mathrm{g}$ total RNA.

Hybridization was performed overnight at $60^{\circ} \mathrm{C}$ with $0.5-1.0 \times 10^{6}$ cpm radiolabelled EPO probe. RNAse digestion with RNAse $A$ and $T 1$ was carried out at $20^{\circ} \mathrm{C}$ for $30 \mathrm{~min}$ and terminated by the addition of proteinase $\mathrm{K}$ and SDS before purification of the protected fragments by phenol/chloroform extraction and ethanol precipitation and electrophoresis on a denaturing $10 \%$ polyacrylamide gel.

Autoradiography of the dried gel was performed at $-70^{\circ} \mathrm{C}$. Protected EPO mRNA bands were excised from the dried gel and counting was performed using a flat-bed liquid scintillation counter (1205; Betaplate $^{\mathrm{TM}}$, Pharmacia-Wallac OY, Turku, Finland). The number of counts per minute obtained from each EPO mRNA sample was divided by the quantity of total RNA analyzed to yield the EPO mRNA abundance (EPO mRNA/ $\mu \mathrm{g}$ total RNA). An external standard, consisting of pooled RNA extracted from the kidneys of severely anemic rats, was used to correct for any difference in quantitation arising between assays. $20 \mu \mathrm{g}$ of the standard was run with each assay and sample EPO mRNA levels were expressed relative to the EPO mRNA count in the corresponding standard, which was assigned an arbitrary value of 1.0. In earlier experiments the results of duplicate RNAse protection assays of RNA prepared from the same organ showed a high degree of reproducibility and assays of different concentrations of RNA prepared from the same organ exhibited linearity of the assay over the experimental range (18).

The total organ quantity of RNA in kidney and liver was calculated from the amount of RNA extracted from aliquots of homogenate derived from known weights of tissue. There was a reproducible linear relationship between the RNA yield and the weight of tissue homogenized.

$E P O$ radioimmunoassay. Serum EPO concentrations were determined as described (19) with the use of a rabbit antiserum raised against pure recombinant human EPO and iodinated recombinant human EPO (Amersham) as tracer. A rat serum pool enriched in EPO was prepared by exposing donor animals to hypoxia and was used as standard after calibration against the II. International Reference Preparation by in vivo bioassay (19). Student's unpaired $t$ test was used for comparison of groups and analysis of variance to determine significance levels of linear regressions. $P<0.05$ was considered significant.

\section{Results}

Body weight, kidney, and liver weight of the animals studied at different ages, the amount of total RNA extracted per gram tissue, and the estimates of the amount of total RNA in both 
organs are given in Table I. In both liver and kidneys the concentrations of total RNA declined slightly during development and at day 54 were $42 \%$ lower in liver and $36 \%$ lower in kidney than in neonatal animals. At each age level the amount of total RNA per gram tissue was about 2-fold higher in liver than in kidney, and considering the differences in organ weight, the liver contained approximately 5- to 8-fold more total RNA than both kidneys during the first three weeks and approximately 10 -fold more on days 28 and 54 .

Measurements of serum erythropoietin concentrations. The serum EPO levels at the different ages under basal conditions and after exposure to normobaric hypoxia or carbon monoxide are given in Fig. 1. Under basal conditions EPO levels were maximal one day after birth $(62.6 \pm 19.2 \mathrm{mU} / \mathrm{ml}$, mean $\pm \mathrm{SE}, n$ $=7$ ) and thereafter declined about 3-fold to reach a level two weeks after birth that was similar to that of adults $(17.7 \pm 5.5$ $\mathrm{mU} / \mathrm{ml}$, mean $\pm \mathrm{SE}, n=3$ ). At all ages animals responded to both stimuli with an increase in EPO levels. The amplitude of this increase, however, was clearly age dependent, with 1.6 -fold and 2.1-fold increases in newborn animals and 12-fold and 87-fold elevations in adults. Consequently the absolute levels of serum EPO were 2- and 12-fold higher in adult than in 1-d old animals ( $208 \pm 55$ versus $98.1 \pm 12.7$ for normobaric hypoxia and $1,543 \pm 141$ versus $133.8 \pm 28.3$ for carbon monoxide stimulation, respectively; mean $\pm \mathrm{SE}, n=8$ [newborn animals] or 3 [adult animals]).

Measurements of erythropoietin $m R N A$. To assess the accumulation of EPO mRNA underlying these age- and stimulusdependent variations in serum EPO concentrations, EPO mRNA in kidney and liver tissue of each animal was determined by RNAse protection assay. For quantitative analysis the abundance of EPO mRNA in each sample (EPO mRNA per $\mu \mathrm{g}$ total RNA) was calculated from the radioactivity of protected fragments, and the value expressed relative to the EPO mRNA count of an external standard that was run on each gel. Figs. 2 and 3 show examples of autoradiographs obtained with RNA from livers and kidneys of rats at different stages of development. The mean values of the relative abundance of EPO mRNA in liver and kidneys of all animals are given in Fig. 4A. Since the concentration of total RNA in liver and kidney is different and changes with age, the responsiveness of EPO gene expression in liver and kidney tissue is more clearly represented when EPO mRNA is related to tissue weight. Accordingly, measurements of the concentration of total RNA in each organ were used to calculate the concentration

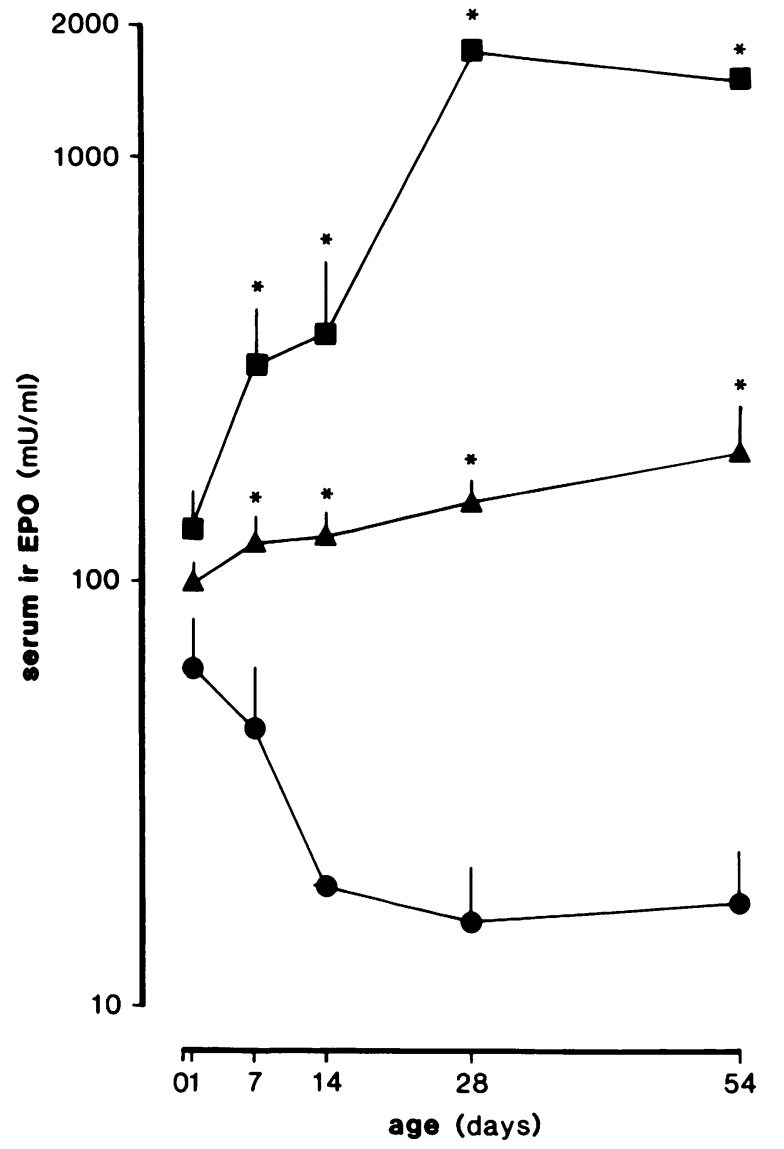

Figure 1. Serum immunoreactive EPO (irEPO) levels in developing rats under unstimulated conditions $(\bullet)$, after $4 \mathrm{~h}$ of normobaric hypoxia $(\Lambda)$, and after $4 \mathrm{~h}$ of carbon monoxide exposure $(\boldsymbol{(})$ (mean $\pm \mathrm{SE}$, $n=7-8$ for 1-d old animals, 6 for 7-d old animals exposed to carbon monoxide, and 3 for all other groups). *Significant difference from unstimulated controls.

of EPO mRNA per gram wet weight of tissue. In addition, organ weights were used to calculate the total EPO mRNA in each organ.

Table II shows the mean values of EPO mRNA concentrations per gram tissue weight at different ages in stimulated and unstimulated rats. Under basal conditions the EPO mRNA concentration on day 1 was eightfold higher in liver than in kidney. Whereas in liver the basal EPO mRNA concentration

Table I. Body Weight and Weight and Total RNA Content of Liver and Kidneys during Development

\begin{tabular}{|c|c|c|c|c|c|c|c|}
\hline \multirow[b]{2}{*}{ Age } & \multirow[b]{2}{*}{ Body weight } & \multicolumn{3}{|c|}{ Liver } & \multicolumn{3}{|c|}{ Kidneys } \\
\hline & & Organ weight & $\begin{array}{l}\text { Total RNA/ } \\
\text { gram tissue }\end{array}$ & $\begin{array}{c}\text { Total organ } \\
\text { RNA }\end{array}$ & Organ weight & $\begin{array}{l}\text { Total RNA/ } \\
\text { gram tissue }\end{array}$ & $\begin{array}{c}\text { Total organ } \\
\text { RNA }\end{array}$ \\
\hline days & \multicolumn{2}{|c|}{$g$} & \multicolumn{2}{|c|}{$m g$} & $g$ & \multicolumn{2}{|c|}{$m g$} \\
\hline $1(n=23)$ & $7.8 \pm 0.6$ & $0.30 \pm 0.03$ & $6.53 \pm 1.18$ & $1.92 \pm 0.31$ & $0.10 \pm 0.01$ & $2.63 \pm 0.39$ & $0.25 \pm 0.05$ \\
\hline $7(n=12)$ & $15.7 \pm 2.3$ & $0.46 \pm 0.08$ & $5.76 \pm 1.40$ & $2.70 \pm 0.98$ & $0.21 \pm 0.03$ & $2.84 \pm 0.58$ & $0.59 \pm 0.17$ \\
\hline $14(n=9)$ & $35.1 \pm 2.2$ & $1.01 \pm 0.09$ & $4.79 \pm 0.35$ & $4.84 \pm 0.27$ & $0.36 \pm 0.04$ & $2.17 \pm 0.20$ & $0.79 \pm 0.10$ \\
\hline $28(n=9)$ & $93.4 \pm 12.4$ & $4.51 \pm 0.77$ & $4.54 \pm 0.77$ & $20.4 \pm 3.9$ & $1.03 \pm 0.13$ & $1.95 \pm 0.17$ & $2.00 \pm 0.18$ \\
\hline $54(n=9)$ & $227.7 \pm 11.2$ & $10.2 \pm 0.9$ & $3.77 \pm 0.79$ & $38.0 \pm 7.2$ & $2.03 \pm 0.18$ & $1.68 \pm 0.25$ & $3.40 \pm 0.50$ \\
\hline
\end{tabular}

Mean \pm SD. 


\section{unstimulated normobaric hypoxia carbon monoxide}

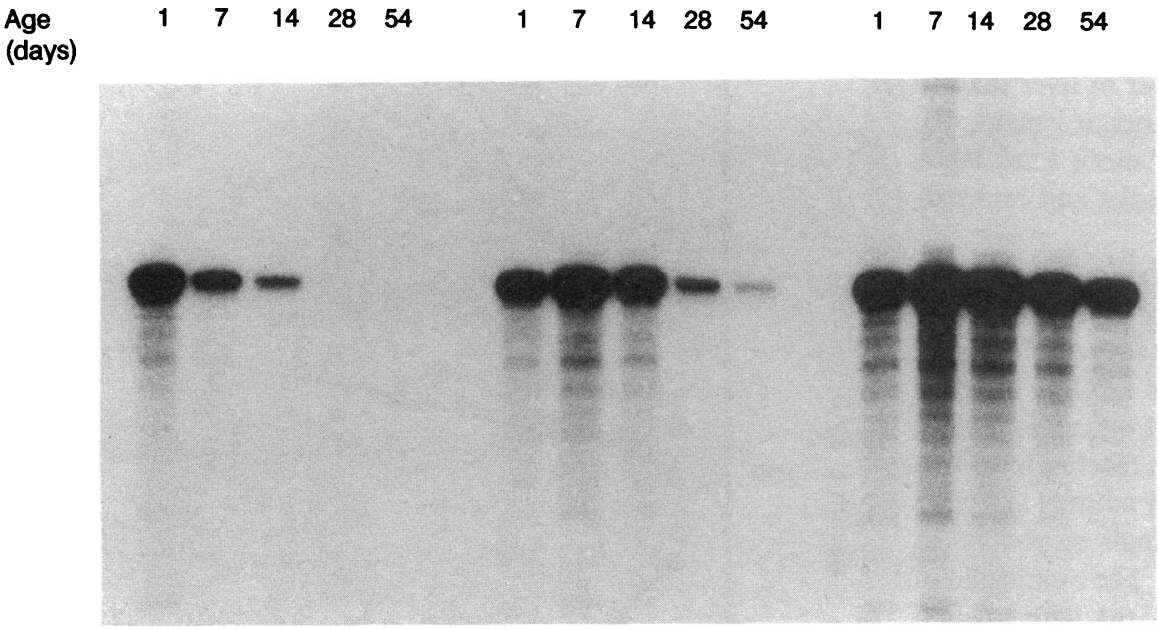

Figure 2. Autoradiograph, after 6-d exposure, of an RNase protection assay of EPO mRNA in the livers of rats under unstimulated conditions, after $4 \mathrm{~h}$ of normobaric hypoxia or exposure to carbon monoxide. $150 \mu \mathrm{g}$ of total RNA extracted from livers of individual animals was analyzed by RNAse protection after hybridization to a ${ }^{32} \mathrm{P}$-labelled transcript complementary to $132 \mathrm{bp}$ of exon $\mathrm{V}$ and $300 \mathrm{bp}$ of the adjoining intron of the rat EPO gene. Note that EPO mRNA signals in livers are maximal on day 1 (unstimulated conditions) or day 7 (normobaric hypoxia and carbon monoxide) and thereafter decline progressively with increasing age.

declined rapidly and was below the quantifiable range by day 28, in kidney the basal EPO mRNA concentration declined fivefold within the first week and thereafter remained within the quantifiable range and varied only slightly. After stimulation EPO mRNA concentration increased in both organs at all ages but the amplitude of the increase and the level attained at different stages of development was quite different between the two organs. Under normobaric hypoxia and after exposure to carbon monoxide the renal EPO mRNA concentration achieved increased progressively with age, with the exception only of a slight decline in 7-d-old animals exposed to normobaric hypoxia, so that by day 54 it was three- and sevenfold higher than in neonates. In contrast the concentration of EPO mRNA achieved in liver tissue in response to both stimuli showed little change between days 1 and 14 but thereafter decreased progressively so that by day 54 the hepatic EPO mRNA concentration was 10-fold less than that in kidney for each stimulus. When comparing the mean increases of renal and hepatic EPO mRNA concentrations after stimulation, it be- comes apparent that the response of EPO mRNA concentration to stimulation by exposure to carbon monoxide was always greater than by exposure to normobaric hypoxia, but the difference generally became more marked with increasing age. However, with the exception of 7-d old animals, in each age group the relative efficacy of exposure to carbon monoxide versus exposure to normobaric hypoxia was similar between liver and kidneys.

The total amount of EPO mRNA in liver and kidneys and the relative contribution of the liver to EPO formation in the whole animal are shown in Fig. $4 \mathrm{~B}$ and Table III. It can be seen that the liver accounts for a remarkably large proportion of the total EPO mRNA and contains the majority of EPO mRNA for the first three to four weeks in both stimulated and unstimulated rats. During this period, however, the predominance of the liver was most pronounced under basal conditions. Thus the liver accounts for more than 94\% of EPO mRNA in unstimulated animals during the first three weeks, whereas under normobaric hypoxia and carbon monoxide, the hepatic contri-

\section{unstimulated}

Age normobaric hypoxia

\section{carbon monoxide}

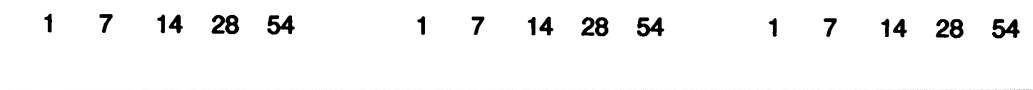

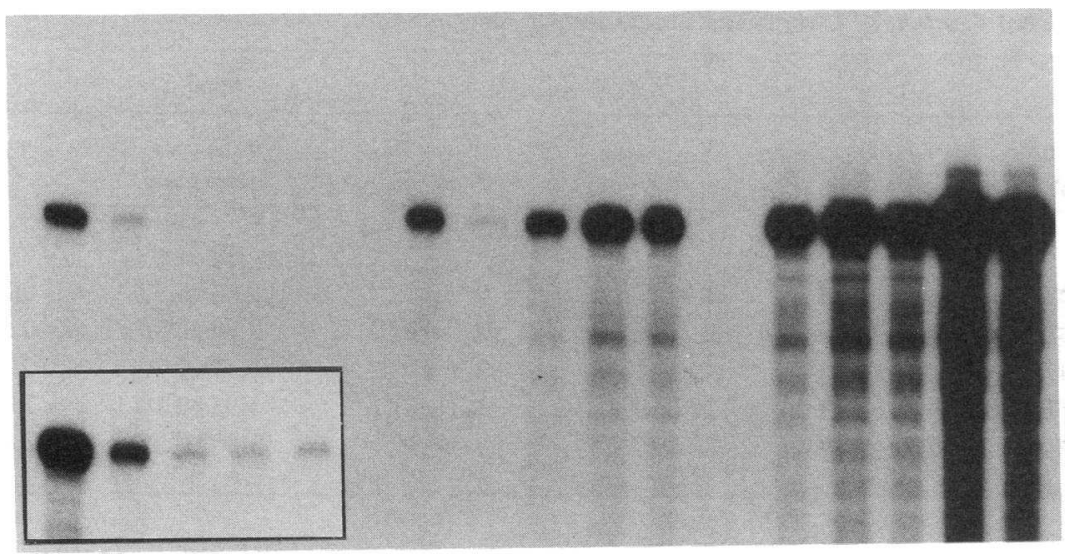

Figure 3. Autoradiograph, after 14-h exposure, of an RNAse protection assay of EPO mRNA in the kidneys of rats under unstimulated conditions, after $4 \mathrm{~h}$ of normobaric hypoxia or exposure to carbon monoxide. $150 \mu \mathrm{g}$ of total RNA from unstimulated animals and animals exposed to normobaric hypoxia was assayed and $100 \mu \mathrm{g}$ of total RNA from animals exposed to carbon monoxide. Inset shows signals of protected fragments in unstimulated animals after 7-d exposure of the autoradiograph. While the abundance of EPO mRNA decreased with age in kidneys of unstimulated animals, under stimulation EPO mRNA signals generally increased with age. 


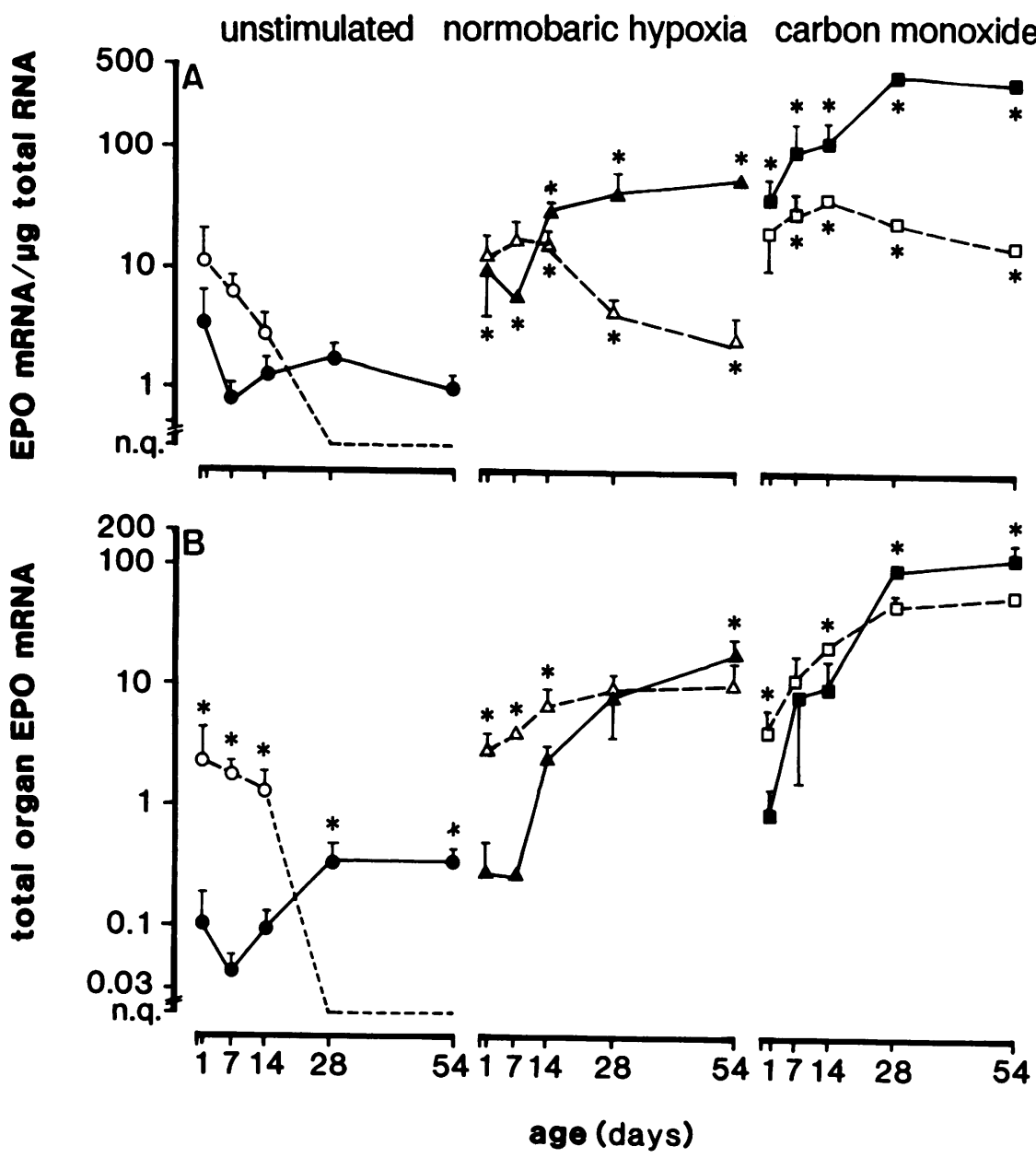

Figure 4. Changes with development in the abundance of EPO mRNA $(A)$ and the total amount of EPO mRNA $(B)$ in rat kidneys (closed symbols) and livers (open symbols). EPO mRNA was quantified by scintillation counting of protected EPO mRNA bands and is expressed as EPO mRNA counts minus background counts per microgram of RNA loaded, divided by standard counts in each gel $\left(\times 10^{-4}\right)$ (see Methods). Values are mean $\pm \mathrm{SD}$, numbers of animals as given in the legend of Fig. 1; n.q., not quantifiable. ${ }^{*}$ In $(A)$ indicates significant difference from the abundance of EPO mRNA in unstimulated animals and in $(B)$ indicates significant difference between the total amount of EPO mRNA in kidney and liver. bution was $91 \%$ and $85 \%$ in neonates. Although this proportion decreased with age under both stimuli, at day 54 the liver still contained on average 32 and $33 \%$ of the total EPO mRNA.

This hepatic contribution of about one-third in adult animals is considerably higher than that which has been previously measured in anemic mice (13) or has been inferred from studies in bilaterally nephrectomized animals (1-3). Additional experiments were therefore performed to investigate if EPO gene expression in rat liver under the above short-term stimulation $(a)$ differs from that during prolonged reductions in hematocrit and $(b)$ differs from that in acutely nephrectomized animals. For this purpose separate groups of adult rats were studied after induction of anemia by repetitive phlebotomy and after exposure to carbon monoxide $(0.1 \%)$ after bilateral nephrectomy.

Experiments with anemic animals. Repetitive phlebotomies on three consecutive days (days 1-3) resulted in a decrease of hematocrit values from $40.4 \pm 3.3 \%$ to $23.4 \pm 0.6 \%, 16.4 \pm 2 \%$ and $13 \pm 1 \%$ on days $2-4$, and a corresponding increase in serum EPO values from $16 \pm 1.6 \mathrm{mU} / \mathrm{ml}$ to $385 \pm 112 \mathrm{mU} / \mathrm{ml}$,

Table II. Renal and Hepatic EPO mRNA Concentrations (EPO mRNA/g Tissue) during Development

\begin{tabular}{|c|c|c|c|c|c|c|c|c|c|c|}
\hline \multirow{3}{*}{$\frac{\text { Age }}{\text { days }}$} & \multicolumn{5}{|c|}{ Liver } & \multicolumn{5}{|c|}{ Kidneys } \\
\hline & \multirow[t]{2}{*}{ Unstimulated } & \multicolumn{2}{|c|}{ Normobaric hypoxia } & \multicolumn{2}{|c|}{ Carbon monoxide } & Unstimulated & \multicolumn{2}{|c|}{ Normobaric hypoxia } & \multicolumn{2}{|c|}{ Carbon monoxide } \\
\hline & & & Relative increase & & Relative increase & & & Relative increase & & Relative increase \\
\hline 1 & $7.96 \pm 7.27$ & $9.10 \pm 4.16$ & (1.1-fold) & $14.00 \pm 8.67$ & (1.8-fold) & $1.00 \pm 0.92$ & $2.78 \pm 1.79$ & (2.8-fold) & $9.07 \pm 5.76$ & (9.0-fold) \\
\hline 7 & $3.33 \pm 0.91$ & $9.04 \pm 2.33$ & (2.7-fold) & $20.30 \pm 13.23$ & (6.1-fold) & $0.19 \pm 0.08$ & $1.49 \pm 0.30$ & (7.8-fold) & $33.96 \pm 26.41$ & (182.6-fold) \\
\hline 14 & $1.26 \pm 0.39$ & $7.71 \pm 2.73$ & (6.1-fold) & $19.80 \pm 1.52$ & (15.7-fold) & $0.25 \pm 0.14$ & $7.05 \pm 1.83$ & (28.2-fold) & $26.06 \pm 11.82$ & (106.0-fold) \\
\hline 28 & nq & $2.00 \pm 0.84$ & - & $11.95 \pm 0.13$ & - & $0.36 \pm 0.15$ & $7.97 \pm 4.39$ & (22.1-fold) & $90.30 \pm 7.59$ & (254.4-fold) \\
\hline 54 & nq & $0.91 \pm 0.43$ & - & $6.04 \pm 0.28$ & - & $0.18 \pm 0.06$ & $8.92 \pm 1.46$ & (49.6-fold) & $59.89 \pm 12.29$ & (327.3-fold) \\
\hline
\end{tabular}

EPO mRNA was quantified by scintillation counting of protected fragments in RNAse protection assays and related to an external standard (see Fig. 4 and Methods). EPO mRNA concentrations per gram wet weight of tissue were calculated from the abundance of EPO mRNA per gram of total RNA (Fig. $4 \mathrm{~A}$ ) and the concentrations of total RNA per gram wet weight of tissue (Table I). mean \pm SD, $n=7-8$ for 1 -d old animals, 6 for 7-d old animals exposed to carbon monoxide, and 3 for all other groups. nq, not quantifiable. 
Table III. Total Amount of EPO mRNA (Sum of Renal and Hepatic EPO $\mathrm{mRNA}$ ) and Proportion of Hepatic EPO mRNA during Development

\begin{tabular}{|c|c|c|c|c|c|c|c|c|c|}
\hline \multirow[b]{2}{*}{ Age } & \multicolumn{3}{|c|}{ Unstimulated } & \multicolumn{3}{|c|}{ Normobaric hypoxia } & \multicolumn{3}{|c|}{ Carbon monoxide } \\
\hline & $\begin{array}{c}\text { Total } \\
\text { EPO mRNA }\end{array}$ & $\begin{array}{c}\text { Total } \\
\text { EPO mRNA/ } \\
\text { body weight }\end{array}$ & $\begin{array}{c}\text { Hepatic } \\
\text { EPO mRNA/ } \\
\text { total } \\
\text { EPO mRNA }\end{array}$ & $\begin{array}{c}\text { Total } \\
\text { EPO mRNA }\end{array}$ & $\begin{array}{c}\text { Total } \\
\text { EPO mRNA/ } \\
\text { body weight }\end{array}$ & $\begin{array}{c}\text { Hepatic } \\
\text { EPO mRNA/ } \\
\text { total } \\
\text { EPO mRNA }\end{array}$ & $\begin{array}{c}\text { Total } \\
\text { EPO mRNA }\end{array}$ & $\begin{array}{c}\text { Total } \\
\text { EPO mRNA } \\
\text { body weight }\end{array}$ & $\begin{array}{c}\text { Hepatic } \\
\text { EPO mRNA/ } \\
\text { total } \\
\text { EPO mRNA }\end{array}$ \\
\hline days & & $g^{-1}$ & $\%$ & & $g^{-1}$ & $\%$ & & $g^{-1}$ & $\%$ \\
\hline 1 & $2.41 \pm 2.19$ & $0.322 \pm 0.30$ & $95 \pm 3.2$ & $3.01 \pm 1.24$ & $0.371 \pm 0.15$ & $91 \pm 5.1$ & $4.77 \pm 2.74$ & $0.616 \pm 0.39$ & $85 \pm 10$ \\
\hline 7 & $1.72 \pm 0.66$ & $0.133 \pm 0.05$ & $98 \pm 0.5$ & $3.76 \pm 0.83$ & $0.289 \pm 0.10$ & $93 \pm 1.4$ & $18.57 \pm 12.89$ & $1.021 \pm 0.69$ & $64 \pm 18$ \\
\hline 14 & $1.44 \pm 0.52$ & $0.041 \pm 0.02$ & $94 \pm 1.2$ & $9.75 \pm 2.17$ & $0.284 \pm 0.08$ & $73 \pm 9.1$ & $30.02 \pm 6.88$ & $0.351 \pm 0.19$ & $69 \pm 11$ \\
\hline 28 & $0.34 \pm 0.14$ & $0.004 \pm 0.00$ & - & $17.99 \pm 5.80$ & $0.189 \pm 0.07$ & $55 \pm 16$ & $141.4 \pm 19.71$ & $1.548 \pm 0.03$ & $35 \pm 2.4$ \\
\hline 54 & $0.34 \pm 0.11$ & $0.001 \pm 0.00$ & - & $29.28 \pm 6.77$ & $0.140 \pm 0.07$ & $32 \pm 12$ & $182.1 \pm 32.62$ & $0.818 \pm 0.14$ & $33 \pm 3.9$ \\
\hline
\end{tabular}

Mean \pm SD; $n=7-8$ for 1-d old animals, 6 for 7-d old animals exposed to carbon monoxide, and 3 for all other groups.

$1,278 \pm 511 \mathrm{mU} / \mathrm{ml}$ and $2,631 \pm 362 \mathrm{mU} / \mathrm{ml}$, respectively (mean $\pm \mathrm{SD}, n=5$ ). The total organ EPO mRNA on day 4 was $157.7 \pm 42.8$ in kidneys and $80.9 \pm 32.8$ in livers (mean $\pm S D$ ); the resulting proportion of hepatic EPO mRNA in relation to the total EPO mRNA was $34.4 \pm 11.5 \%$ (mean \pm SD) and not significantly different from that following short-term exposure to hypoxic hypoxia or carbon monoxide.

Experiments with nephrectomized animals. The amount of EPO mRNA and serum EPO levels in adult rats exposed to carbon monoxide $7 \mathrm{~h}$ after bilateral nephrectomy are shown in Fig. 5. It can be seen that the serum EPO levels reached were only $17 \%$ of those reached in the sham-operated controls. However, hepatic EPO mRNA accumulation in the liver of nephrectomized animals was also significantly reduced to $\sim 55 \%$ of that observed in the sham-operated controls.

Relationship of erythropoietin $m R N A$ to serum erythropoietin concentrations during development. To facilitate comparison of EPO mRNA content with serum EPO concentration, the total EPO mRNA content (the sum of renal and hepatic EPO mRNA content) for stimulated and unstimulated animals at different ages was normalized to the body weight (Table III). When expressed in this way, the total EPO mRNA in animals of a particular age was related linearly to the serum EPO concentration. This relationship was seen over a wide range of

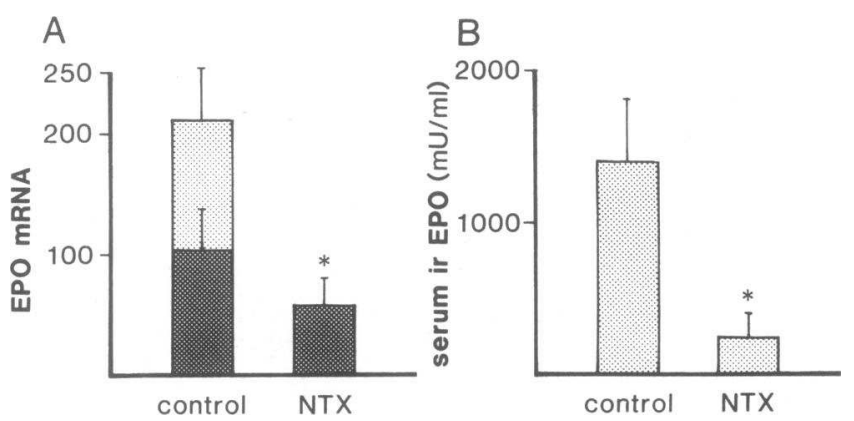

Figure 5. EPO mRNA $(A)$ and serum immunoreactive EPO (ir EPO) $(B)$ in rats exposed to carbon monoxide $7 \mathrm{~h}$ after bilateral nephrectomy $(N T X)(n=7)$ and in sham-operated controls $(n=7)$. $(A)$ dark shadowing illustrates EPO mRNA in livers and light shadowing EPO mRNA in kidneys of control animals. Quantitation of EPO mRNA as in Fig. 4. *Significant difference in the amount of hepatic EPO mRNA $(A)$ and serum hormone levels $(B)$. stimulated values irrespective of whether stimulation was by normobaric hypoxia or by exposure to carbon monoxide, as shown in Fig. 6. However, the slope of the regression was not the same for each age group and increased progressively during development, being approximately ninefold greater in 54-d-old animals than in 1-d old animals. Thus, when normalized for body weight, the total EPO mRNA content achieved under the most powerful stimulus was approximately constant with development (Table III), whereas the corresponding serum EPO levels increased markedly (Fig. 1).

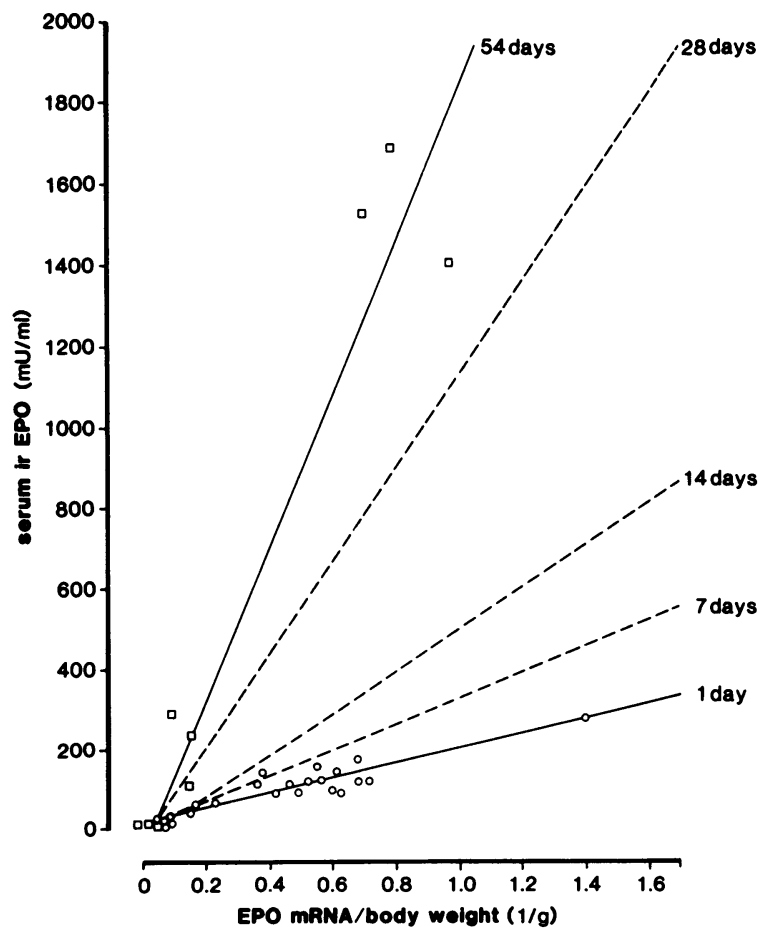

Figure 6. Relationship between the total amount of EPO mRNA in the animals, i.e., the sum of renal and hepatic EPO mRNA, normalized for body weight and the serum immunoreactive EPO (ir EPO) concentrations. At each age level serum hormone levels correlated linearly with EPO mRNA (day $1: P<0.0001, \mathrm{r}^{2}: 0.86$; day $7: P<$ $0.0001, \mathrm{r}^{2}: 0.89$; day 14: $P<0.002, \mathrm{r}^{2}: 0.77$; day 28: $P<0.0001, \mathrm{r}^{2}$ : 1.00; day 54: $\left.P<0.0001, \mathrm{r}^{2}: 0.93\right)$. Individual values are included only for the youngest $(0)$ and oldest animals $(\square)$ investigated. 


\section{Discussion}

A major control mechanism for EPO formation has been found to operate by modulation of $\operatorname{EPO} \operatorname{mRNA}(11,12,20)$ and this investigation demonstrates significant alterations in the amount of EPO mRNA in rat kidneys and liver during development, which is basically in accordance with the age dependence of the effects of bilateral nephrectomy and hepatectomy on EPO formation $(2,5,6,10)$. In contrast to anemic mice, as recently shown by Koury et al. (13), in the present study the hepatic proportion of EPO mRNA was considerable, accounting for the majority of EPO mRNA during early postnatal life and for about one-third of EPO mRNA during adulthood (Fig. $4 B$, Table III). The predominance of the liver in neonatal and juvenile animals was found irrespective of whether the animals were stimulated or not and regardless of whether the stimulus was normobaric hypoxia or exposure to carbon monoxide. Irrespective of changes with age the hepatic proportion of the total EPO mRNA was in fact very similar under these two stimuli at 1, 14, and 54 days, and somewhat lower only at 7 and 28 days in the carbon monoxide group (Table III). Furthermore, although these stimuli were applied for a short time only, the liver appears not to respond primarily in the early phase of hypoxia, since the hepatic contribution was also about one-third in adult animals with more prolonged reductions in hematocrit. Thus, despite the differences in the mode of limitation of oxygen delivery during normobaric hypoxia, exposure to carbon monoxide, or anemia, there was no striking difference between the relative sensitivity of liver and kidney to each stimulus and under all conditions tested the liver accounted for a surprisingly high proportion of the total. Clearly, however, all stimuli were relatively severe, so that our results may demonstrate the potential for hepatic gene expression rather than what is achieved under less severe stimulation.

For a given stimulus, there was a continuous decline of the proportion of hepatic EPO mRNA with increasing age, resulting in a "shift" of the predominance from liver to kidneys between three and four weeks. This shift was not due to a reduction in the total amount of EPO mRNA in the liver, but rather resulted from a greater increase in the total amount of EPO mRNA in the kidneys (Fig. $4 \mathrm{~B}$ ). When organ weight is taken into consideration, it is evident that the concentration of EPO mRNA per gram liver tissue decreased with increasing age of the animals, whereas the converse was true for renal EPO mRNA concentrations (Table II). Recently, EPO gene expression was demonstrated by in situ hybridization in parenchymal as well as nonparenchymal murine liver cells (21). However, the type and size of the hepatic cell populations producing EPO at different stages of development are yet unknown. If the number of hepatic EPO-producing cells increases in proportion to liver growth, than the results suggest that for a given stimulus these cells produce progressively less EPO after about two weeks of life (Table II). Alternatively, the findings may indicate that subpopulations of hepatic cells that produce EPO proliferate less rapidly than the majority of liver cells. In the kidneys EPO mRNA increased out of proportion to the increase in organ weight during development (Table II). Interestingly, in this regard, in adult mice with varying degrees of anemia, the modulation of EPO mRNA has been shown to reflect variations in the number of cells in the renal cortical interstitium that express the EPO gene, with individual cells expressing the gene in an essentially all-or-none manner (22). Whether the age-dependent increase in EPO mRNA also results from an increasing recruitment of cells remains to be investigated.

When considering the significance of the accumulation of EPO mRNA, an important question arises with regard to the efficiency with which EPO mRNA in liver and kidneys is translated to achieve a rise in serum hormone concentrations under different stimuli and at different stages of development. If one assumes that the distribution volume for EPO, that has been shown in adult rats to correspond to plasma volume (23), is proportional to body weight, it appears justifiable to compare serum EPO levels with the total amount of EPO mRNA, i.e., the sum of renal and hepatic EPO mRNA, after it has been normalized by body weight. At each age level, this comparison revealed significant linear relationships (Fig. 6), a result in keeping with the view that mRNA accumulation is the major control mechanism of EPO formation. Interestingly, however, the slope of this relationship increases about ninefold during development. Thus serum EPO levels at a given stimulus increased with age (Fig. 1), an observation in accordance with previous studies $(2,5,10,24,25)$, although the total amount of EPO mRNA when normalized for body weight was either constant or even declined with age (Table III).

This age-dependent change in the relationship between EPO mRNA and the circulating hormone concentrations could arise by several mechanisms which the present study cannot clearly differentiate. Age-dependent alterations in both EPO production and metabolism, e.g., a decrease in distribution volume or clearance rate of the hormone are possible. With regard to EPO clearance rate some evidence has in fact recently been provided in humans that the half life time of EPO in neonates $(26)$ is shorter than that in adults $(27,28)$. On the other hand, the fact that the increase in the ratio between serum EPO levels and EPO mRNA coincides with the shifting of EPO gene expression from liver to kidneys, raises the question whether the translational efficiency in the liver is less than that in the kidneys, or whether a proportion of the newly synthesized hormone in the liver cannot enter the systemic circulation, since the liver is probably a major site of EPO clearance. Interestingly in this regard, no EPO was detected by Fried et al. (29) or Caro et al. (25) by bioassay for EPO in liver extracts of hypoxic newborn and developing rats; and Clemons et al., using a radioimmunoassay, found less EPO in the liver than in the kidneys of hypoxic rats as early as two days after birth (24). Furthermore, although the age dependence of the effect of bilateral nephrectomy on EPO formation shown by others $(2,5,6$, 10 ) is completely in accordance with the shift of EPO mRNA accumulation as observed in this study, a putative discrepancy appears to arise with regard to the quantitative contribution of the liver; while we found more than $30 \%$ of total EPO mRNA in the livers of adult rats (Fig. 4, Table III), several studies showed that serum EPO levels after bilateral nephrectomy are reduced to $\sim 10-15 \%(1-3,30)$. To further investigate the cause of this difference we measured EPO mRNA accumulation in the livers in a separate group of bilaterally nephrectomized rats.

Interestingly, as shown in Fig. 5, the amount of hepatic EPO mRNA in the nephrectomized animals was significantly reduced to $\sim 55 \%$. This suggests that, due to an inhibition of EPO gene expression in the liver, studies in nephrectomized animals may have underestimated the contribution of the liver to EPO formation. Furthermore, since serum EPO levels after nephrectomy were only slightly more reduced than the total 
amount of EPO mRNA, it appears unlikely that the relationship between EPO mRNA and effective EPO production rate in the liver is generally much lower than in the kidneys. Thus the disproportionality between EPO mRNA and serum EPO levels during development is probably not primarily due to a switch in the site of production.

In conclusion, this study shows that: (a) despite a markedly increasing responsiveness of developing rats in terms of serum EPO levels under hypoxia, the amount of EPO mRNA, when related to body weight, is rather constant or even decreasing during development; $(b)$ the liver contributes more than $50 \%$ to the total amount of EPO mRNA for up to four weeks of life; and $(c)$ in adult animals the contribution of the liver under strong stimulation is more significant than previously recognized.

\section{Acknowledgments}

The technical assistance of U. Bolliger and C. Gasser is gratefully acknowledged.

This work was supported by the Swiss National Science Foundation (grant 31-9433.88), the Hartmann Müller Foundation for Medical Research, and the National Kidney Research Fund, Medical Research Council and Wellcome Trust, United Kingdom.

\section{References}

1. Jacobson, L. O., E. Goldwasser, W. Fried, and L. Plzak. 1957. Role of the kidney in erythropoiesis. Nature (Lond.). 179:633-634.

2. Schooley, J. C., and L. J. Mahlmann. 1972. Erythropoietin production in the anephric rat. I. Relationship between nephrectomy, time of hypoxic exposure, and erythropoietin production. Blood. 39:31-38.

3. Wang, F., and W. Fried. 1972. Renal and extrarenal erythropoietin production in male and female rats of various ages. J. Lab. Clin. Med. 79:181-186.

4. Fried, W. 1972. The liver as a source of extrarenal erythropoietin production. Blood. 40:671-677.

5. Carmena, A. O., D. Howard, and F. Stohlman. 1968. Regulation of erythropoiesis XXII. Erythropoietin production in the newborn animal. Blood. 32:376382.

6. Peschle, C., G. Marone, A. Genovese, C. Cillo, C. Magli, and M. Condorelli. 1975. Erythropoietin production by the liver in fetal-neonatal life. Life Sci. 17:1325-1330.

7. Zanjani, E. D., E. N. Peterson, A. S. Gordon, and L. R. Wasserman. 1974. Erythropoietin production in the fetus: role of the kidney and maternal anemia. J. Lab. Clin. Med. 83:281-287.

8. Zanjani, E. D., J. Poster, H. Burlington, L. I. Mann, and L. R. Wasserman 1977. Liver as the primary site of erythropoietin formation in the fetus. $J$. Lab. Clin. Med. 89:640-644.

9. Zanjani, E. D., J. L. Ascensao, P. B. McGlave, M. Banisadre, and R. C. Ash 1981. Studies on the liver to kidney switch of erythropoietin production. J. Clin. Invest. 76:1183-1188.

10. Gruber, D. F., J. R. Zucali, J. Wleklinski, V. LaRussa, and E. A. Mirand.
1977. Temporal transition in the site of rat erythropoietin production. Exp. $H e$ matol. (NY). 5:399-407.

11. Bondurant, M. C., and M. J. Koury. 1986. Anemia induces accumulation of erythropoietin mRNA in the kidney and liver. Mol. Cell. Biol. 6:2731-2733.

12. Beru, N., J. McDonald, C. Lacombe, and E. Goldwasser. 1986. Expression of the erythropoietin gene. Mol. Cell. Biol. 6:2571-2575.

13. Koury, M. J., M. C. Bondurant, S. E. Graber, and S. T. Sawyer. 1988 Erythropoietin messenger RNA levels in developing mice and transfer of ${ }^{125} \mathrm{I}$-erythropoietin by the placenta. J. Clin. Invest. 82:154-159.

14. Abbrecht, P. H., and J. K. Littell. 1972. Plasma erythropoietin in men and mice during acclimatization to different altitudes. J. Appl. Physiol. 32:54-58.

15. Eckardt, K.-U., J. Dittmer, R. Neumann, C. Bauer, and A. Kurtz. 1990. Decline of erythropoietin formation at continuous hypoxia is not due to feedback inhibition. Am. J. Physiol. 258:F1432-F1437.

16. Tan, C. C., K.-U. Eckardt, and P. J. Ratcliffe. Organ distribution of erythropoietin messenger RNA in normal and uraemic rats, studied by RNAse protection. 1991. Kidney Int. 40:69-76.

17. Ratcliffe, P. J., R. W. Jones, R. E. Phillips, L. G. Nicholls, and J. I. Bell 1990. Oxygen-dependent modulation of erythropoietin mRNA levels. J. Exp. Med. 172:657-660.

18. Potter, C. G., C. C. Tan, and P. J. Ratcliffe. 1991. Quantification of ${ }^{32} \mathrm{P}$-labelled samples in gelö fragments using the flat-bed liquid scintillation counter. Anal. Biochem. 197:121-124.

19. Eckardt, K.-U., A. Kurtz, P. Hirth, P. Scigalla, L. Wieczorek, and C. Bauer. 1988. Evaluation of the stability of human erythropoietin in samples for radioimmunoassay. Klin. Wochenschr. 66:241-245.

20. Schuster, S. J., E. V. Badiavas, P. Costa-Giomi, R. Weinmann, A. J. Erslev, and J. Caro. 1989. Stimulation of erythropoietin gene transcription during hypoxia and cobalt exposure. Blood. 73:13-16.

21. Koury, S. T., M. C. Bondurant, M. J. Koury, and G. L. Semenza. 1991. Localization of cells producing erythropoietin in murine liver by in situ hybridization. Blood. 77:2497-2503.

22. Koury, S. T., M. J. Koury, M. C. Bondurant, J. Caro, and S. E. Graber. 1989. Quantitation of erythropoietin-producing cells in kidneys of mice by in situ hybridization: correlation with hematocrit, renal erythropoietin mRNA, and serum erythropoietin concentration. Blood. 74:645-651.

23. Spivak, J. L., and B. B. Hogans. 1989. The in vivo metabolism of recombinant human erythropoietin in the rat. Blood. 73:90-99.

24. Clemons, G. K., S. L. Fitzsimmons, and D. De Mannicor. 1986. Immunoreactive erythropoietin concentrations in fetal and neonatal rats and the effects of hypoxia. Blood. 68:892-895.

25. Caro, J., A. J. Erslev, R. Silver, O. Miller, and G. Birgegard. 1982. Erythropoietin production in response to anemia or hypoxia in the newborn rat. Blood. 60:984-988.

26. Ruth, V., J. A. Widness, G. K. Clemons, and K. O. Raivio. 1990. Postnatal changes in serum immunoreactive erythropoietin in relation to hypoxia before and after birth. J. Pediatr. 116:950-954

27. Eckardt, K.-U., U. Boutellier, A. Kurtz, M. Schopen, E. A. Koller, and C. Bauer. 1989. Rate of erythropoietin formation in humans in response to acute hypobaric hypoxia. J. Appl. Physiol. 66:1785-1788.

28. Cotes, P. M., M. J. Pippard, C. D. L. Reid, C. G. Winearls, D. O. Oliver, and J. P. Royston. 1989. Characterization of the anaemia of chronic renal failure and the mode of its correction by a preparation of human erythropoietin ( $r$ HuEPO). An investigation of the pharmacokinetics of intravenous erythropoietin and its effects on erythrokinetics. Q. J. Med. 262:113-137.

29. Fried, W., J. Barone-Varelas, and T. Barone. 1980. The influence of age and sex on erythropoietin titers in the plasma and tissue homogenates of hypoxic rats. Exp. Hematol. 10:472-477.

30. Erslev, A. J., J. Caro, R. Kansu, and R. Silver. 1980. Renal and extrarenal erythropoietin production in anaemic rats. Br. J. Haematol. 45:65-72. 